vent. -80909

DETA 000174

\title{
ELECTROLYTIC GETTERING OF TRITIUM FROM AIR
}

\author{
P. C. SOUERS \\ .R..T. TSUGAWA \\ C. G. STEVENS
}
30 th NATIONAL AVS SYMPOSIUM BOSTON, MASSACHUSETTS

November $1-4,1983$

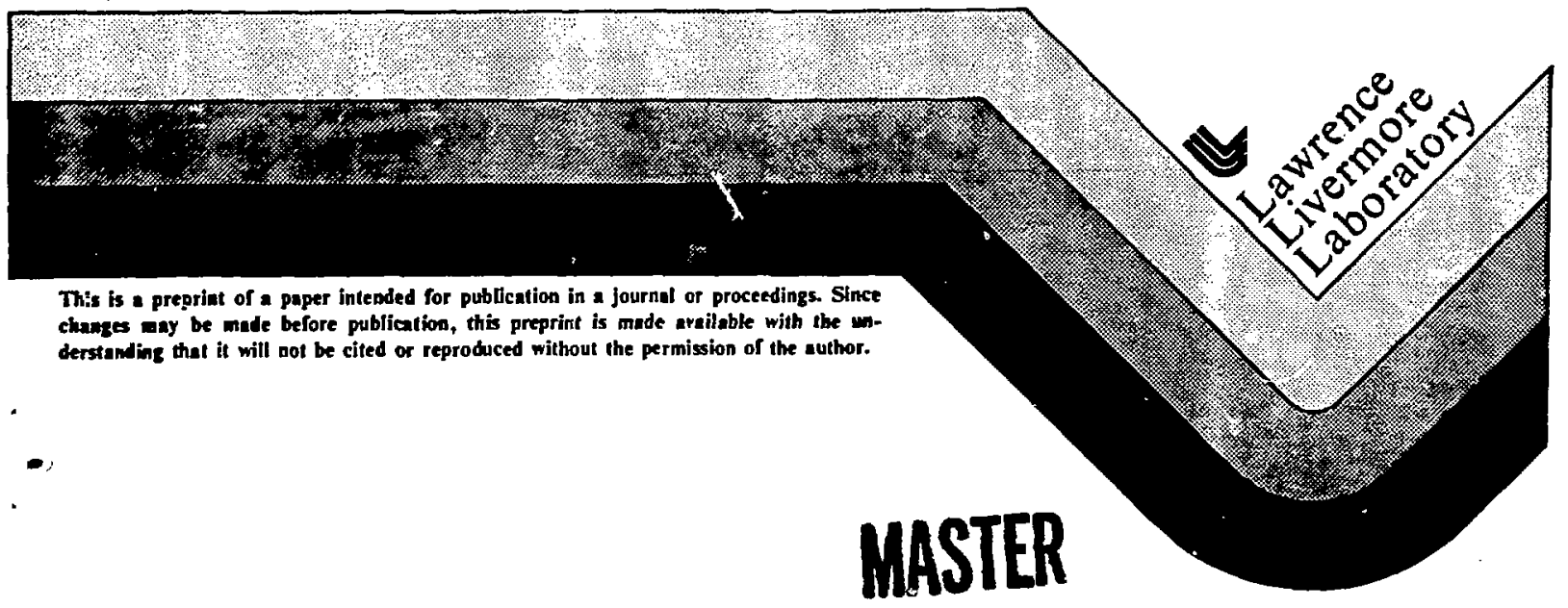




\section{ELECTMULYTIC GETTERING OF TRLTIUN FROH AIR}

\section{P. C. Souere, R. T. Trugawa and C. G. Scevent}

Lawrence Livermore National Laboratory, Livermore, Callfornia

We have renoved $90 \%$ of 1 part-per-million tritiun 8 ; in air of 257 to 357 humidity by the d.c. electrical action of the solid proton electrolyte hydrogen uranyl phosphate (HUP). Gettr ting takes 5 to 24 hours for a $1 \mathrm{~cm}^{2}$ HUP disc at 2 to $4 \mathrm{~V}$ in a static, 1200 ce gas volume. Hydrogen gas may be used to flush captured tritium through the HUP. Liquid water leaches out the tritium but water vapor is ineffective. This technique prom ses an alternative to the conventional catalyst/zeolite method. PACS Numbers: 81.40. Rs, 66.30.-h, 77.20+y

\section{INTRODUCTION}

Deuterium-tritium is the likely fuel for hydrogen fusion reactors. A possible but undesirable occurrence at such a reactor is the accidental release of tritium into the room air. The present method of cleaning tritium from air is to pass all the room air over a hot palladium or platinum catalyst, which turns the tritium gas to tritiated water, which is then adsorbed on a zeolite bed. There are two problems with this approach. The first is that tritiated water is about 25,000 times as dangerous 
a cricilu gas. 1 This ratio hes incressed chrough the yeare. not because water has been determined to be nore dangerous. but becaute the sas appear: to be lese $10 .{ }^{2}$ With protective clothing ano breathing apparatus, the ratlo of hazard way be as great at $10^{6} .3$

The second problem with the catalyst/zeolite technique is cost. Sherwood has proposed the following equation for cost $c_{i}^{4}$

$$
C(\$) \sim 3 \times 10^{4} Q^{0.6} \operatorname{lnD}
$$

where $Q$ is the flow-rate in $\mathrm{m}^{3} / \mathrm{min}$ and $D$ is the ratio of tritium in to tritium out. Equation 1 is good to perhaps $\pm 50 z$. For a laboratory of $400 \mathrm{~m}^{3}$ and 992 clean-up, the cost is approximately $\$ 5$ million. Clearly, it would be desirable to have a cheaper technique.

Metal powders getter tritium in inert atmospheres but fail in air. 5 We have previously experimented with solid acetylenes catalyzed with platinum or palladium at room temperature, but tritiated water was again the apparent product. 6

We here use the solid proton electrolyte, hydrogen uranyl phosphate (HUP), which has the chemical formula $\mathrm{HUO}_{2} \mathrm{PO}_{4} \cdot 4 \mathrm{H}_{2} \mathrm{O}$ and one of the highest a.c. electrical conductivities known: about 0.01 to $0.5 \mathrm{~s} / \mathrm{m}$ at room temperature. ${ }^{7-9}$ Most work has supplied the protons as ions from aqueous acidic solutions, but the HUP has been operated in gaseous hydrogen ${ }^{10}$ and is reported to have been used as well with solid 
hyarideu." 11 A.c. measurements are generally used to avoid polorization effecte, but one d.c. etudy hes been dome. 10 the HUP Corat a eandwich-1ike seructure with the $\left(\mathrm{UO}_{2} \mathrm{PO}_{4}\right)^{-}$ion In one plane and a hydrogen-bonded -O-H- network in the other. 12 The proton passes through the -0-H- network by hopping from one oxyzen atos to another whenever " bydrogen "hole" In che structure permits. It oppears that all hydrogens are mobile, although only one in nine carries a charge. This results in a large proton density of $5 \times 10^{27}$ charges/m 9.13 and a low proton mobility of about $10^{-9} \mathrm{~m}^{2} / \mathrm{V} \cdot \mathrm{s}$. The electrical conductivity has been measured as being 100 times greater in the -O-H- plane than perpendicular to it. 9 The ratio would probablay be even larger in a single crystal. HUP is unusual among solid proton electrolytes in retaining its "water of hydration" in dry air. It is apparently stable at room cemperature to as low as $2 \%$ humidity. 14

\section{EQUIPMENT AND PROCEDURE}

The HUP is such an easy compound to make that a standard syntbesis exists, ${ }^{15,16}$ which we shall briefly describe. Ten grams of uranyl nitrate hexahydrate is dissolved in $50 \mathrm{ml}$. distilled water and $8.4 \mathrm{ml}$. of $2.4 \mathrm{M}$ phosphoric acid (Eastman or Mallinckrodt) is added. After one to two hours, the fine crystals formed are removed in a Buchner funnel. The crystals are washed with $\mathrm{PH} 2$ aqueous phosphoric acid. The paper with the sample is air-dried to constant weight, and the canary yellow crystals are then stored in humid air. 
The we semples are ande as follows. He first punch two 316 eteiblese steel frit disce (Pall Trinity Microcorp. Crade E with $35 \mathrm{~m}$ pores) of $12.7 \mathrm{andiemeter}$ and $1.6 \mathrm{me}$ thick. These are crusbed for 5 alnutee et 6000 pound force in a 1/2-inch dianeter die to produce disce of $1.27 \mathrm{~cm}^{2}$ eree. Sharp extrusion points on the gdget ere resoved. One frit is placed in the die and $5-8$ bo. of palladiu black is spread over the frit surface. The palladiu black nust be added to the anode face or the HUP unit will not work. We next add $0.23 \mathrm{~g}$ of carefully ground HUP. This is spread evenly and then is lightly compressed with a punch. The other frit is added onto the HUP, and the whole is pressed at 6000 lbs. force for 24 to 72 hours. The pressed HUP part of this sandwich is $0.5 \mathrm{~mm}$ thick and is a translucent greenish yellow. The final assembly is checked for electrical short circuits, wires are spot welded to the frits and the edges are epoxied. We $r$ an the experiment in two ways. In the single-bulb mode, the HUP unit sits in a gold-plated stainless ateel container of $1200 \mathrm{cc}$ with both sides open to the same tritium-air mixture. In the double-bulb mode, the HUP is glued to the end of a glass tube to form an air-tight seal between two chambers of $1200 \mathrm{cc}$ volume each. The tritium-air mixture is placed on the anode side and argon of $10 \%$ humidity is placed on the cathode side. We expect the tritium to be oxidized at the anode forming tritons which are then attracted through the HUP to the cathode. 


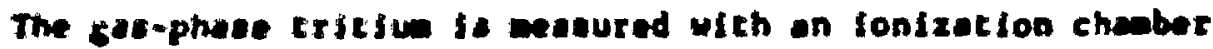
and the vacer vapor with a Panemetric aluana-capacitance device. The d.c. potential and curtent across the HUP is monitored. When coapleted, the HUP-unit is taken apart and each port dissolved and counted in a seintillation counter. The HUP itself is dissolved in dilute nitric scid which is then wixed with United Technologies Packard Insta-Gel counting fluid. At the end of the experiment, the closure for all tritium is usually $\pm 5 \%$.

All sapples are a nominal 1 part-per-million $T_{2}$ gas in "zero air", i.e., bottled air with a dew point of $-77^{\circ} \mathrm{C}$. This mixture is fairly strble when kept in stainless steel bottles, as there is an apparenc drop in the $T_{2}$ gas concentration of perhaps $50 z$ over a year. The desired amount of water vapor is added when the experiment begins. All experiments are at $0.1 \mathrm{MPa}$ ( 1 atm) total pressure and diffusion at room temperature moves tritium through the air to the HUP.

\section{EXPERIMENTAL RESULTS}

Figure 1 shows the tritium gettering results for air of $35 \%$ humidity. Sample 48 was left for 24 hours with no potential and only $4 \%$ of the tritium was adsorbed. The application of $4 \mathrm{~V}$ d.c. started the gettering in this double-bulb run. Sample $\$ 51$ shows the full potential of $4 \mathrm{~V}$ applied immediately in a single-bulb configuration. Sample $\$ 53$ shows the slower gettering with $2 \mathrm{~V}$ applied at the start. Counting later showed the tritium to indeed be in the HUP. 


\section{wete that both $4 \mathrm{~V}$ runs above end with 102 of the tritiun}

remalalos. Hever did we go below thie level. By cold-erapping and counting, we found that this extra teitiun is alwaye HTO. which is exchanged off the unbaked vessel walls in the presence of water vapor. Despite puaping at roon temperature, enough tritius

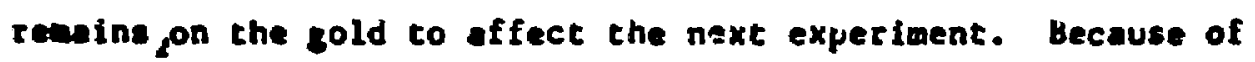
this background effect, we arf not able to ascertain the vitimate possible performance of the HUP or whether the HUP itself is partly responsible for the HTO formation.

Before running any samples, we routinely measured the a.c. properties with a Wayne-Kerr a.c. bridge at $1592 \mathrm{~Hz}$. The samples of Fig. 1 all showed typical "good" initial values of 2 to $3 \times 10^{-3} \mathrm{\Omega}^{-1}$ conductance and 1.4 to $1.6 \mu \mathrm{F}$ capacitance. By the end of the $4 \mathrm{~V}$ runs, the conductance was still $2 \times 10^{-3} \Omega^{-1}$ but the capacitance had degraded to $1.2 \times 10^{-3} \mathrm{WF}$. The $2 \mathrm{~V}$ sample, however, ended at $1.3 \mu F$, which shows that the lower potential causes less damage. This "degradation" is reported as being caused by hydrogen reducing the phosphate groups of the HUP, ${ }^{17}$ although we know of no direct evidence for this process. It could also be loss of water of hydration or the pulling away of the electrodes from the HUP. Whatever it is, the decrease in a.c. capacitance appears to be a qualitative measure of the destruction of the HUP's tritium gettering capacity. The same degradation is seen also in the d.c. current. 
the hove woted thac Pd black to needed, probably an an clectricel contact, on che anode. We aust sak, then, if the id is gettering the critlue. A sapple of 0.27 ed black $(40$ tites that on the HUP) was puped to $10^{-6} \mathrm{P}=$ at $670 \mathrm{~K}$. reacted with hydrogen for 24 hours and pumped agin to high vacuun. The saple briefly, sees air as it is put into the bulb, where it is puaped to $10^{-4}$ pa at room temperature before starting the run. The results are shown in Fig. 2. Pd black will getcer tritium in dry aix, but water vapor ( 307 humidity) greatly diminishes its performance. The blank is the empty ionization chamber with moist tràtium and air.

We also tried runs at 0.5 to $0.8 \mathrm{~V} \mathrm{~d} . \mathrm{c}$. , potentials low enough to avoid ionization of water at the anode or formation of water at the cathode. We also wished to avoid possible electrochemical reactions in che HUP. As an example, run $\$ 56$ gettered $23 \%$ of the tritium at $0.5 \mathrm{~V}$ in 67 hours, and only $0.8 \%$ appeared on the cathode side. But run $\$ 57$, handled in an identical way, transferred $46 \%$ of the tritium to the cathode side in 72 hours, and only $6 \%$ remained in the HUP. The presence of air on the cathode side confirmed a leak through the HUP. The low voltage runs then merely highlighted the problem of small cracks and tritium gettering was proportionately reduced by the lower potential. No special behavior was seen.

Let us return to our "standard" HUP unit following a successful $4 V$ gettering. How can we get the tritium out again? In one case, we added $55 \%$ humidity to the argon on the cathode 
Iide of a double bulb run and reversed the $4 v$ pocential. Over 52 houre, only $9 x$ of the teltiva in the HUP ewerged back into the air on the originel anode side. In another case, the potential was increased to $10 \mathrm{~V}$ in the forward gettering direction, but the anode bulb triciun rose within minutes from 0.11 to $0.54 \mathrm{kPm}$. Rossibly, the HUP was dehydrating or decomposing, so that use of the lowest possible potential is clearly desirable. We twice place' gettered "HUP" discs in liquid water, and the tritium was leached out with a $1 /$ e-time of about 5 to 10 hours, so that all tritium was effectively gone in 24 hours. Clearly, the HUP does not bind the tritium tightly.

After yet another gettering in the double-bulb mode, we flushed out the air-tritium on the anode side and added $27 \mathrm{kPa}$ $\mathrm{H}_{2}$ gas of $17 \%$ humidity as a hydrogen source. Figure 3 shows the flushing of the tritium through the HUP into the cathode bulls. By integrating the current plus following the cathode build-up of hydrogen gas, we find that we have replaced all the hydrogen in the huP over 3 times in order to move $80 \%$ of the tritium across the $0.5 \mathrm{~mm}$ thickness of the HUP. In this run, $2 \%$ of the original tritium left the HUP and went back into the anode bulb air. In other hydrogen flushes, from 10 to $40 \%$ of original tritium reappeared in the anode gas. These experiments again confirm the view that the gettered tritium is close to the anode surface of the HUP and flushing it through requires moving much or all of the hyarogen in the HUP interior. 


\section{V. DISCUSSION}

We should next like to consider various HUP properties.

Figure 4 showe the d.c. electrical conductivity versus potential for 1 wa HUP sauples. We see that hydrogen gas is a me efficient source of protons than water (pH 4) or moist air. For the latter two, the upper curve is for fresh HUP and the lower curve for degraded HUP following a day's experiments.

The lowest curve in Fig. 4 is $1 \mathrm{~mm}$ HUP with solid gold blocking electrodes and the sample completely sealed in epoxy. This was a repeat of Shilton and Howe's similar experiment in which they derived an upper value of electronic conductivity of $10^{-6} \mathrm{~s} / \mathrm{m}$ at $1 \mathrm{~V}$ at room temperature. ${ }^{8}$ We are not sure this is electronic or some sort of chemical reaction. We tried as well a "standard" HUP sample epoxied front and back to prevent hydrogen from entering or leaving. After 26 minutes at $4 \mathrm{~V}$, the sample blew apart on the cathode side, which we take as evidence that hydrogen was trying to come of the porous cathode frit.

One of the most remarkable effects with the HUP is its residual voltage. For example, we gettered tritium for 167 hours at $2 \mathrm{Vd.c.} \mathrm{At} \mathrm{the} \mathrm{end} \mathrm{of} \mathrm{this} \mathrm{time,} \mathrm{we} \mathrm{removed} \mathrm{the} \mathrm{power} \mathrm{supply}$ and rewired the HUP unit across a 1 M resistor. We found a residual potential across the resistor of $1.82 \mathrm{~V}$. Careful experiments sijowed that the polarity was the same as that originally applied with our external power supply. We next took out the resistor and put an ammeter in. The potential across the 


\section{K ameter realstance dropped to sear-zero in 3 wlinutes with}

\section{cotal discharge current of about $3 \times 10^{18}$ charges. The $1 \mathrm{ma}$}

cestecor was replaced and the reafdus potentiel gradually rose back to $0.87 \mathrm{y}$.

The HUP shows large dielectric constant of about $3 \times 10^{5}$ at the gtart and 300 at the end of a run. This could be caused by space charging near the plates or at grain boundaries or possibly by residual ferroelectric ordering. 9 The effect of space charging is to block the electric in the interior of the sample and allow conductivity only in a skin layer of thickness ${ }^{18}$

$$
\lambda=\left(2 \mathrm{k} \varepsilon_{\mathrm{o}} \mathrm{U} / \mathrm{Ne}\right)^{1 / 2}
$$

where $U$ is the d.c. potential, $K$ the dielectric constant, $\epsilon_{0}=8.85 \times 10^{-12} \mathrm{C} / \mathrm{V} \cdot \mathrm{m}, \mathrm{N}$ the charge density (taken to be $5 \times 10^{27}$ charges $/ \mathrm{m}^{3}$ ) and $\mathrm{e}=1.602 \times 10^{-19} \mathrm{C} /$ charge. ${ }^{18}$ If this effect is present, it would allow tritium gettering only in a thin layer near the anode with a low leakage of current through the bulk of the HUP sample.

The interesting properties of HJP offer a hope that tritium gas can, indeed, be directly gettered from air. One can visualize flat panels of elecrolytic getter fixed on the walls of laboratories and reactor rooms or massed in large dead-space tanks. It may be possible to carry out the gettering by passing the contaminated air over the panels with uothing more expensive than a low power blower. This offers the enticing possibility of the development of a cheaper tritium clean-up system. 


\section{ACKNOWLEDGEMENTS}

We would like to thank Gene Nardella, Greg Haas and Jack Baublitz (now moved elsewhere) of the office of Fusion Energy, Department of Energy, for their support of this work. We greatly appreciąte the local efforts of Bob Borchers of the LLNL Magnetic Fusion Program. One of us (P.C.S.) would especially like to thank Gene Nazdella for his moral support in the search for new tritium concepts through the years. Work performed under the auspices of the U.S. Department of Energy by the Lawrence Livermore National Laboratory under contract No. W-7405-ENG-48.

1. C. E. Easterly and J. E. Phillips, Proceedings: Tritium Technology in Fission, Fusion and Isotopic Applications, American Nuclear Society National Topical Meeting, April 29-May 1, 1980, Dayton, Ohio, L. J. Wittenberg, ed., U.S. Department of Energy CONF-800 427 (1981), Pp. 19-24.

2. A. E. Sherwood, Lawrence Livermore National Laboratory, Livermore, California, 94550, private communication, 1982.

3. T. P.Fuller and C. E. Easterly, Tritium Protective Clothing, Oak Ridge National Laboratory Report ORNL/TM-6671 (1973).

4. A. E.Sherwood, reference 2, private communication, 1981.

5. C. W.Schoenfelder and L. A. West, Radiation Effects and Tritium Technology for Fusion Reactors, Proc. Int. Conf. Gatlinburg, Tennessea, October 1-3, 1975, J.S. Watson and F. W. Wiffen, ed., CONF-750 989 (1976), III, PP. 482-506.

6. P. C. Sovers, E. R. Bissell, G. D. Honore, L. C. Kang, R. T. Tsugawa and H. H. Miller, J. Vac. Sci. Technol. 20, 1132 . (1982). 
7. N. G. Shition and A. T. Howe, Mat. Mes. Bull. 12.701 (1471).

- A. T. Howe and M. C. Shilicon, J. Solid scate Chem. 26. 345 (1979).

9. A. T. Howe and M. G. Shilicon, J. Solid State Chem. 34. 149 (1900).

10. J. S. Lundageard, J. Malling and M.L.S. Birchall, Solid State lonics 2. 53 (1982).

11. P. E. Childs, A. T. Howe and H. G. Shilton, J. Power Sources 3. 105 (1978) .

12. B. Morosin, Phys, Lett. 65A, 53 (1978).

13. M. G. Shilton and A. T. Howe, J. Solid State Chem. 34, 137 (1980).

14. A. T. Howe and M. G. Shilton, J. Solid State Chem. 31, 393 (1980).

15. J. M. Schreyer, Inorganic Syntheses, T. Moeller, ed. (McGraw-Hill, New York, 1957), Vol. V, PP. 150-152.

16. P. M. Childs, A. T. Howe and M. G. Shilton, J. Solid State Chem. 34, 341 (1980).

17. U. Chowdhry, J. R. Barkley, A. D. English, and A. W. Sleight, Mat. Res. Bull. 17, 917 (1982).

18. H. A. Hoyen, Jr., J. A. Strozier, Jr. and C. Y. Li, Surf. Sci. 20, 258 (1970).

\section{DISCLAIMIER}

This document was prepared as an account of mork sponsored by an agency of the United States Government. Neither the Linited States Government nor the tiniversity of California nor any of their employets, makes any warranty, express or :mplied, or assumes any legal liability or responsibility for the accuracy, completeness, or usefulness of any information, apparatus, product, or process disclosed, or represents that its use would not infringe privately owned rights. Reference herein to any specific commercial products, process, of service by trade name, trademark. manufacturer, or othernise, does not necessarily constiule or imply its endorsement, recommendation, or favoring by the United States Govemment or the University of California. The views and opinions of authors expressed here in do not necessarily state or reflect those of the United States Government thereof, and shall not be used for advertising of product endorsement purposes. 


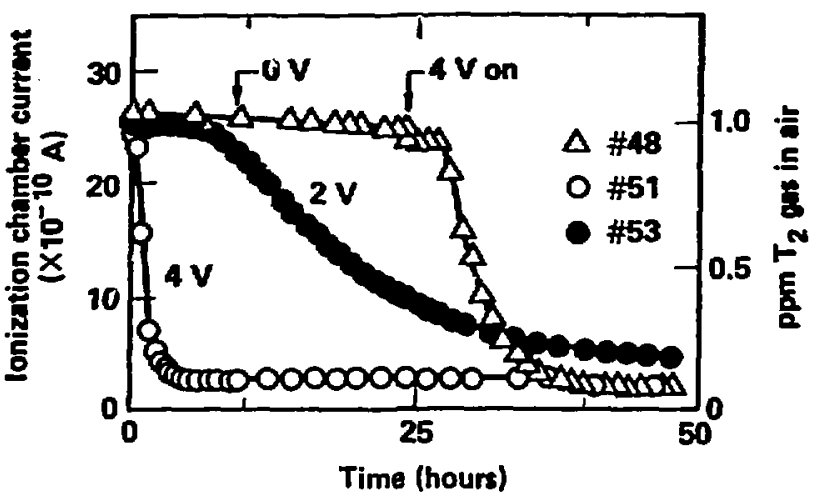

Fig. 1. Tritium gettering curve:, for $1 \mathrm{ppm} \mathrm{T}_{2}$ gas in air of 3,6 humidity. 


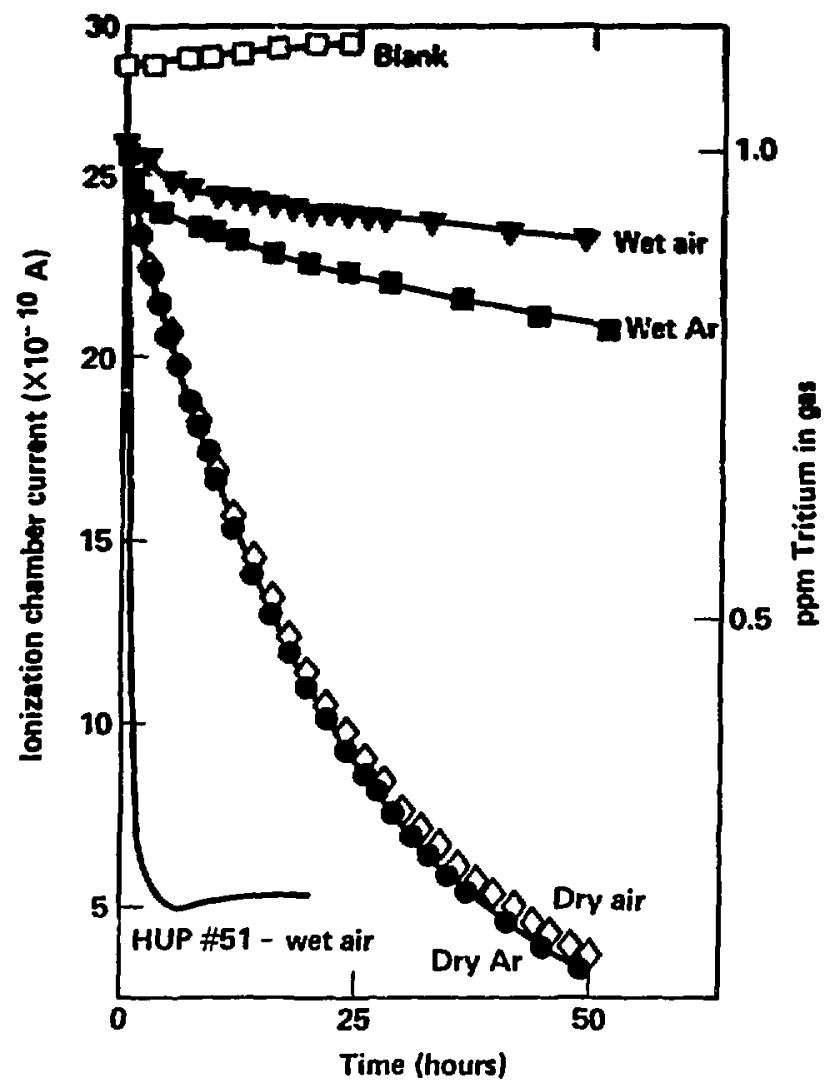

Fig. 2. Kettering of $1 \mathrm{ppm} \mathrm{T}_{2}$ with $0.27 \mathrm{~g}$ palladium black. total gas pressure is $0.1 \mathrm{MPa}$ at room temperature. A fast HUP gettering is shown for comparison. "Wet" air is $25 \%$ to $35 \%$ humidity. 


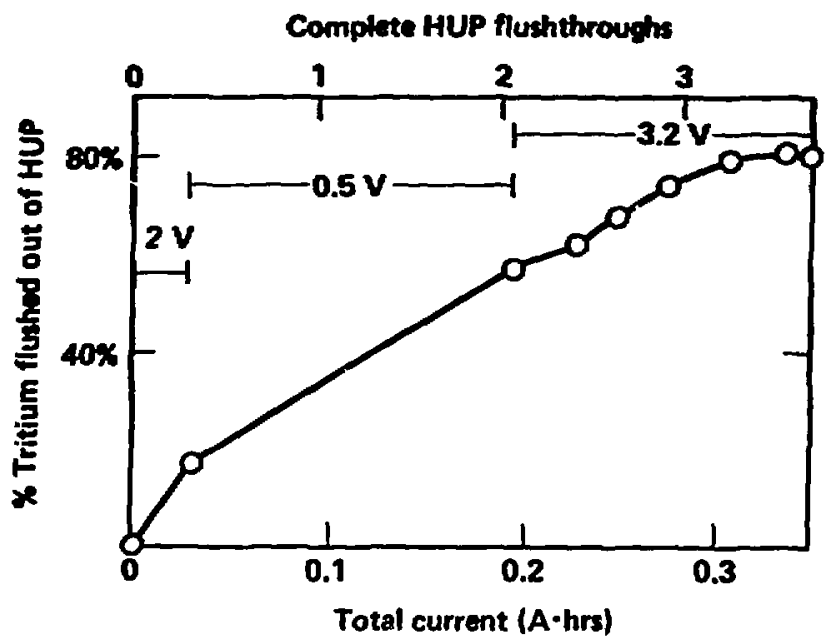

Fig. 3. Flushthrough of tritium in HUP using $\mathrm{H}_{2}$ gas. $300 \%$ tritium on the $Y$-axis corresponds to $72 \%$ gettered tritium initially by the HUP. 


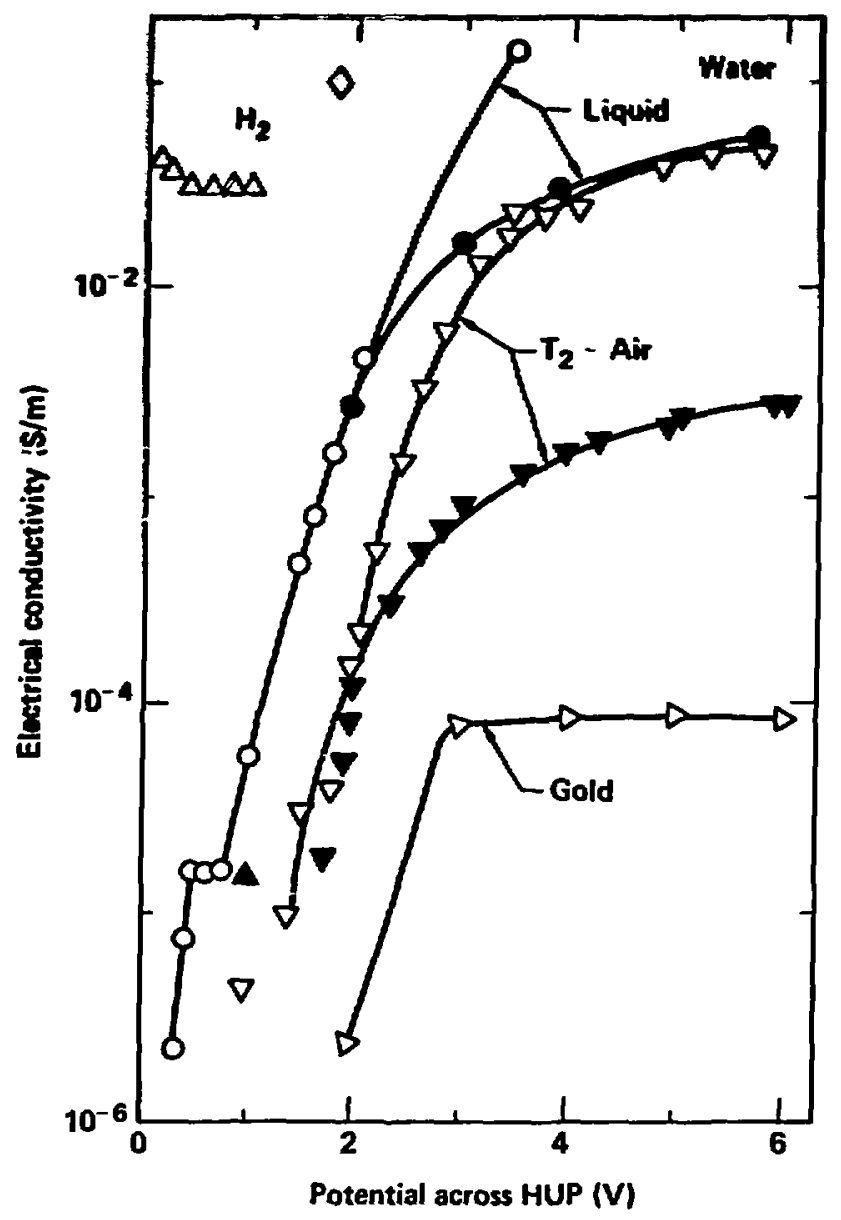

Fig. 4. D.c. electrical conductivity versus potential curves for HUP samples. The $\mathrm{H}_{2}$ is at 13 to $26 \mathrm{kPa}$; the $\mathrm{T}_{2}$-in-air sample has $20 \%$ humidity. The gold blocking electrodes prevent hydrogen ions from entering or leaving the samples. The liquid water and air samples start high but degrade to the lower curves. 